\title{
Jody Heyman, Forgotten Families: Ending the Growing Crisis Confronting Children and Working Parents in the Global Economy
}

\author{
Maureen E. Kelly
}

Published online: 18 April 2007

(C) Springer Science+Business Media, LLC 2007

\section{Erratum to: J Fam Econ Iss DOI 10.1007/s10834-006-9041-8}

The title of the above book review by Maureen E. Kelly is incorrect in the online version.

The online version of the original article can be found at http://dx.doi.org/10.1007/s10834-006-9041-8

M. E. Kelly ( ()

Norton School of Family and Consumer Sciences, University of Arizona, Tucson, AZ 85721-0033, USA

e-mail: mekelly@Ag.arizona.edu 